\title{
Multiphase mafic dykes in the Caledonides of northern Finnmark revealed by a new high-resolution aeromagnetic dataset
}

\author{
Aziz Nasuti', David Roberts' \& Laurent Gernigon' \\ ${ }^{1}$ Geological Survey of Norway, P.O. Box 6315 Sluppen, 7491 Trondheim, Norway. \\ E-mail corresponding author: aziz.nasuti@ngu.no
}

\begin{abstract}
New high-resolution aeromagnetic data from northern Finnmark provide confirmatory evidence for the existence of both metadolerite and unmetamorphosed dolerite dykes transecting the Caledonian nappes and subjacent (par)autochthonous lithostratigraphical successions from Magerøya in the west to Varanger Peninsula in the east. Three ages of mafic dykes are known from isotopic dating studies - Ediacaran, Late Devonian and Early Carboniferous - but actual dyke outcrop in the case of the two younger dyke sets is very limited. High-amplitude magnetic responses in two thrust sheets in northwestern Varanger Peninsula, north of the TKFZ and beneath the Tanahorn Nappe, are clearly shown to relate to swarms of Ediacaran metadolerite dykes. Individual dykes discontinuously exposed on the surface can be followed as linear positive magnetic anomalies over distances of $25 \mathrm{~km}$ inland. Their extent offshore is not discussed here because it is beyond our data coverage in this paper. In eastern Varanger Peninsula, 8-9 dolerite dykes of Late Devonian age occur in discontinuous or limited outcrop. The new aeromagnetic data show, however, that up to 20 such dykes can be identified in the subsurface in the region between Vardø and Syltefjorden based on their linear positive magnetic anomaly signatures. South of the TKFZ, two Late Devonian dolerite dykes, well known from small coastal outcrops, are clearly visible as linear positive magnetic anomalies both on land and offshore beneath the sea-floor of Varangerfjorden. The most spectacular manifestations of what we consider to represent blind dolerite dykes are seen in connection with linear positive magnetic anomalies relating to Early Carboniferous dolerite dykes exposed on Magerøya and western Digermul Peninsula. These prominent linear anomalies follow many of the mapped NW-SE- to WNW-ESE-trending faults that have disrupted the Caledonian nappes in this part of Finnmark, and some are continuous over distances of more than $100 \mathrm{~km}$ from Magerøya to western Varanger Peninsula. These particular dykes and faults have been interpreted as relating to a major period of extension and rifting that occurred in the SW Barents Sea and adjacent onshore areas of Norway in Carboniferous time.
\end{abstract}

Keywords: dyke, fault, aeromagnetic, Finnmark, Caledonides, North Norway

Received 17. June 2015 / Accepted 4. October 2015 / Published online 16. November

\section{Introduction}

The Caledonides of Finnmark, northern Norway, are dominated by metasedimentary successions of Neoproterozoic to Early Palaeozoic age. Polyphase structural deformation and particularly thrusting have dissected these diverse successions into innumerable thrust sheets, nappes and nappe complexes, with principal tectonothermal episodes in Late CambrianEarly Ordovician (Rice \& Frank, 2003; Kirkland et al., 2008) and Mid Silurian (Andersen, 1981; Corfu et al., 2006, 2011) time, depending on position in the overall tectonostratigraphy. There is also evidence, on Varanger Peninsula, of a pre-Caledonian, Ediacaran, orogenic event, the Timanian (Roberts, 1995; Roberts \& Olovyanishnikov, 2004; Herrevold et al., 2009), extending northwestwards from its type area in Russia.

In two of the main nappes there are prominent and extensive, ultramafic-mafic complexes, each with associated sets of mafic dykes. Elsewhere, in several thrust sheets, there are significant numbers of mafic dykes with diverse trends, and locally these reach up to swarm proportions (Roberts, 1975; Rice et al., 2004), notably on Varanger Peninsula. Until recently, the only 
aeromagnetic surveys of the land area of Finnmark dated back to the years 1959-1972. A description of the vintage magnetic anomalies in parts of the county was first presented by Åm (1975), and this was expanded upon over a wider area by Olesen et al. $(1990,1992)$. Since that time there have been considerable advances in data acquisition techniques and data processing procedures, but with attention focused largely on the Barents Sea offshore regions. Only in recent years have two highresolution aeromagnetic surveys in the southern Barents Sea overlapped the onshore areas and islands of northern Finnmark (Gernigon et al., 2007; Brönner et al., 2009), with significant results for onshore geology and linkages with the offshore realm (Gernigon et al., 2014).

In the present contribution, following a brief summary of the geology of northernmost Finnmark, we outline the acquisition and processing procedures of the new, high-resolution, aeromagnetic surveys FRAS-12 and TROFI-14 carried out as part of the Geological Survey of Norway's Mineral Resources in North Norway (MINN) programme. These datasets reveal spectacular linear, positive, magnetic anomalies that we interpret to represent blind continuations of mafic dykes which are otherwise poorly exposed on today's land surface. Three disparate ages of mafic dykes are known from isotopic and geochemical studies - Ediacaran, Late Devonian and Early Carboniferous - and a summary is presented of the attributes of these different dyke sets prior to describing the aeromagnetic anomaly patterns.

\section{Regional geology: a summary}

The southeasternmost front of the Caledonides in Finnmark is characterised by a thin, autochthonous, sedimentary succession of Ediacaran to Cambrian age, known as the Dividal Group (Føyn, 1967), lying directly beneath the lowermost thrust sheet. The basal conglomeratic unit of this succession lies unconformably on a peneplaned surface of Neoarchaean and Palaeoproterozoic crystalline rocks. On Varanger Peninsula, in the Tanafjorden-Varangerfjord Region (Fig. 1), the autochthon and parautochthon are represented by several formations of the Vadsø Group of inferred Tonian to Cryogenian age (Vidal, 1981; Siedlecka, 1985). Three major nappe complexes and a higher nappe overlie the (par)autochthonous successions. These are, in ascending order: (1) Gaissa Nappe Complex; (2) Laksefjord Nappe Complex; (3) Kalak Nappe Complex; and (4) Magerøy Nappe (Fig. 1).

The metasedimentary rocks of the Laksefjord and Kalak nappe complexes are intruded by numerous mafic dykes which were metamorphosed to varying degrees during the Caledonian orogeny. Such dykes, metadolerites, are more common in the Kalak Nappe Complex, and especially in the highest Sørøy-Seiland Nappe which hosts the voluminous Seiland Igneous Province, but they are also found quite abundantly, and as swarms, in lower thrust sheets in northern parts of Varanger Peninsula (Roberts, 1975). On this same peninsula there are also younger, nonmetamorphic, dolerite dykes of Late Devonian age (Guise \& Roberts, 2002). In the Magerøy Nappe, on the island Magerøya, the Early Silurian, Honningsvåg Igneous Complex (Robins, 1998; Corfu et al., 2006) intrudes metasedimentary rocks also of Early Silurian age, but no mafic dykes of this age have ever been recorded (B. Robins, pers. comm., 2015). Following Scandian orogenesis in the Magerøy Nappe in Mid Silurian time, there is a gap in the geological record before intrusion of NW-SE-trending dolerite dykes of Early Carboniferous (Visean) age (Lippard \& Prestvik, 1997). These are the youngest mafic dykes yet recorded in Finnmark. As we will show later, these particular dykes are strikingly represented in the new, high-resolution, aeromagnetic dataset. For more comprehensive details of the stratigraphy, sedimentology, structural geology and metamorphism of the Finnmark Caledonides we refer to papers by Banks et al. (1971), Andersen (1984), Roberts (1985), Siedlecka (1985), Gayer et al. (1987), Rice et al. (1989), Kirkland et al. (2006), Herrevold et al. (2009), Corfu et al. (2011) and Roberts \& Siedlecka (2012), and references therein.

\section{New high-resolution aeromagnetic data}

Magnetic data are commonly used on a regional scale for the delineation of regional structures (basins, basement highs, regional fault structures) in either the early and/or advanced stages of sedimentary basin and/or basement investigation (Hinze et al., 2013). Aeromagnetic data in particular have been applied in investigating the basement and deeper structures of the Barents Sea region (Åm, 1975; Skilbrei, 1995) and have recently been used to model the 3D crustal architecture of the adjacent Barents Sea shelf (Barrère et al., 2009; Marello et al., 2013; Gernigon et al., 2014). Ground or aeromagnetic methods are the conventional geophysical approach to the detection of dykes by sensing their induced and/ or remanent magnetism. If a dyke is magnetic and has contrast with its host rocks, then it can be detected and mapped using these methods. As most dykes are fairly thin, elongated bodies they therefore appear as linear features in magnetic maps.

Because of diurnal artefacts, navigation errors and poor resolution of the vintage magnetic data acquired in the 1970s and 1980s, the pre-existing magnetic dataset of the Finnmark region (Skilbrei et al., 1992; Olesen et al., 2010) was of relatively low quality and not entirely reliable for accurate qualitative and quantitative interpretation at the basin scale. Consequently, a systematic remapping of the entire Finnmark region with state-of-the-art, highresolution aeromagnetic data was required in order to update and replace the vintage magnetic field dataset (Fig. 


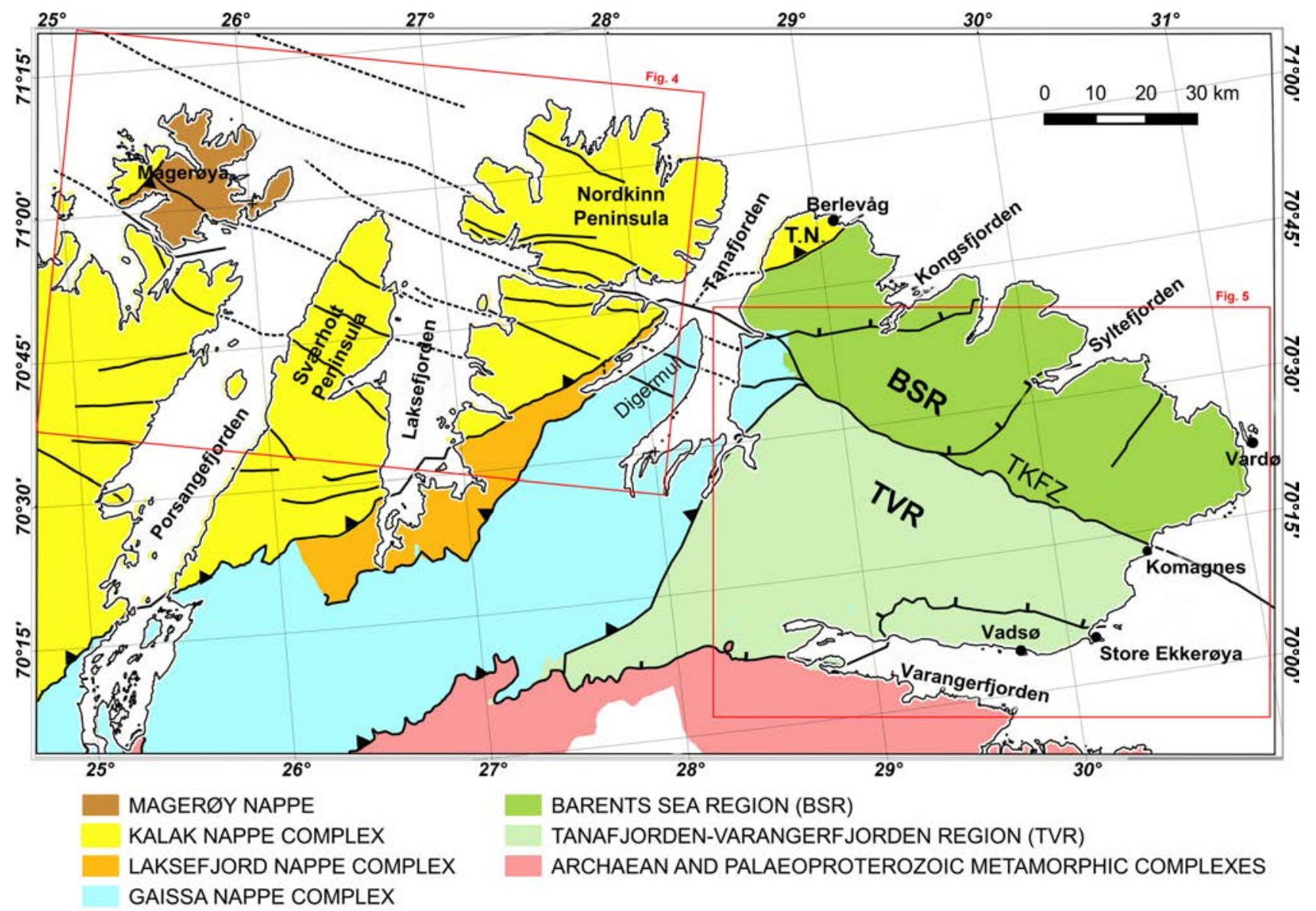

Figure 1. Simplified tectonostratigraphic map of the Caledonides of northernmost Finnmark showing some of the major faults and thrusts. The thrusts are tagged on their upthrust sides. Structures ascribed to the Timanian orogeny occur in the eastern part of Varanger Peninsula (the large peninsula between Tanafjorden and Varangerfjorden). The outlines of Figs. 4 \& 5 are shown by the red boxes. Abbreviations: TKFZ Trollfjorden-Komagelva Fault Zone, T.N. - Tanahorn Nappe.

2). Acquired during the summers of 2011,2012 and 2014, the new FRAS-12 and TROFI-14 surveys, compiled and presented in this paper, cover most of northern Norway, extending from the coastline of Troms and Finnmark up to the Finnmark Platform at around $71^{\circ}$ North. The new aeromagnetic offshore surveys were carried out in a line/ tie-line configuration with profile spacings of $0.2 / 2 \mathrm{~km}$ (for FRAS-12 E), 0.25/2.5 km (for TROFI-14 E), 0.5/5 $\mathrm{km}$ for (TROFI-14 C) and 1/10 km (for TROFI-14 W) (Fig. 2A; Table 1). Clearly, the aeromagnetic resolution for our entire study area is not uniform and is thus highly dependent of the flight-line spacing. During the acquisition, the sensor altitude adopted a nominal drape flying altitude between 60 and $200 \mathrm{~m}$.

The relatively high number of tie-lines accounts for the large diurnal variations as they occur in such high-latitude areas and were therefore required to ensure a proper processing and levelling of the data. Several external, timevarying, field factors usually influence and cause errors during aeromagnetic acquisition. These include altitude variations, magnetic effects of seawater swells and diurnal variations of the magnetic field which usually explain the errors at crossover points between lines and tie-lines. The most complex and significant problem is probably the diurnal variation of the Earth's magnetic field influenced by solar winds, which is particularly important in such northern latitudes. Even though all the new surveys were carried out during a cycle of low solar activity, diurnal variations in the magnetic field still remained and caused tie line and regular survey lines to have different readings at intersections. These effects are usually visually distracting, particularly on image-enhanced displays and would produce artefacts during interpolation and consequently erroneous interpretation if not suitably corrected. The raw data have been processed using both statistical and microlevelling methods (using the Oasis Montaj software) and have considered base station corrections. $91,210 \mathrm{~km}$ of new aeromagnetic profiles have been originally acquired by NOVATEM airborne geophysics (Novatem, 2012, 2014) and EON Geosciences (EON Geosciences Inc., 2015) on behalf of the Geological Survey of Norway (NGU). The final compilation with pre-existing magnetic surveys has been carried out at NGU. 


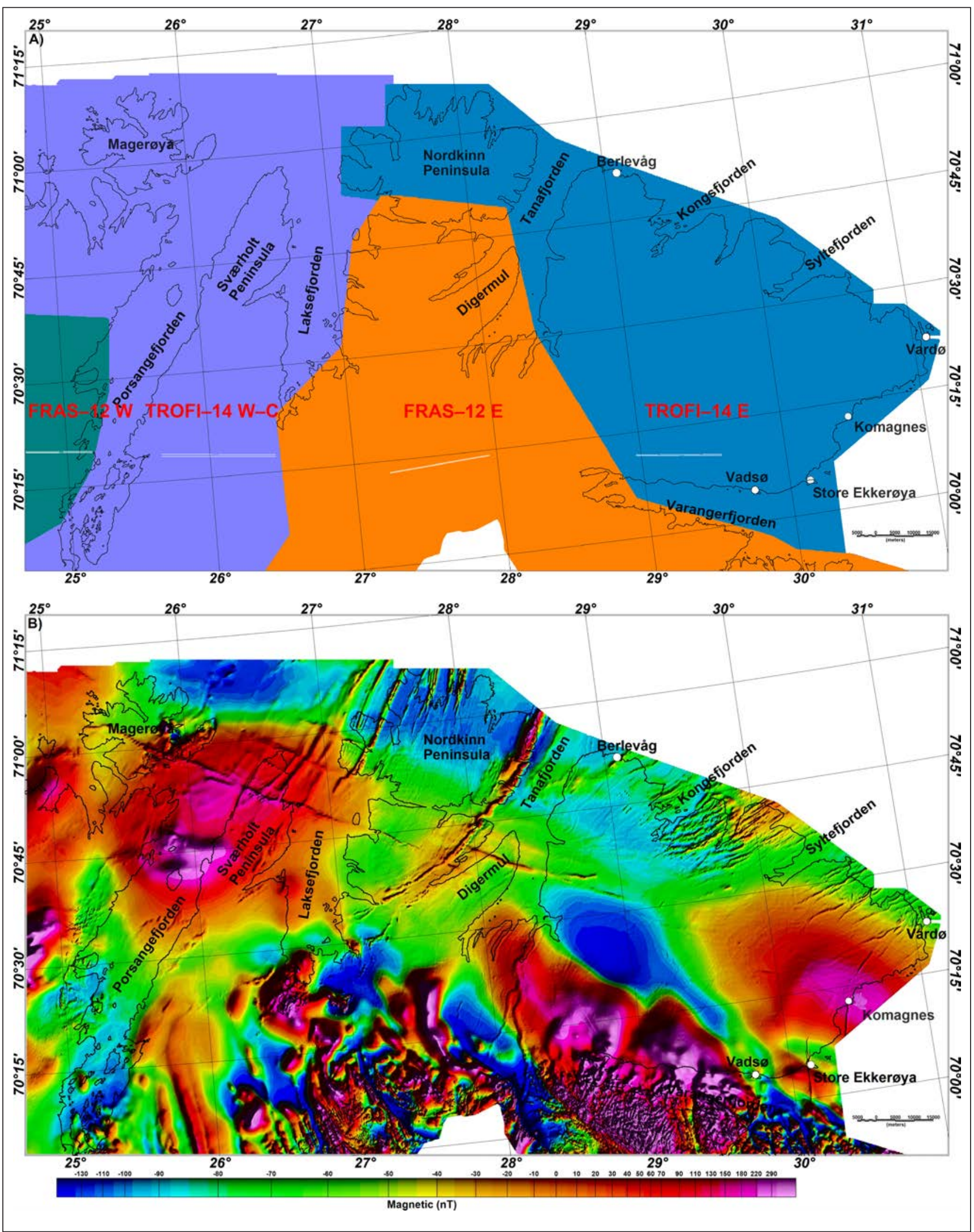

Figure 2. (A) Outlines of the magnetic surveys that have been used in this paper. This magnetic compilation is part of the MINN project at NGU (Nasuti et al., 2015). The different surveys are shown in different colours. The flight line directions are depicted by two small white lines on the map (see the text and Table 1 for more details). (B) Aeromagnetic map of the northern Finnmark Caledonide region between Magerøya and eastern Varanger Peninsula. 
Table 1. Main configurations of the new aeromagnetic surveys.

\begin{tabular}{|c|c|c|c|c|c|c|c|}
\hline Surveys & Period & $\begin{array}{c}\text { Line/tie spacing } \\
(\mathrm{km})\end{array}$ & Line $\mathrm{km}$ & $\begin{array}{c}\text { Average flight } \\
\text { altitude }\end{array}$ & Magnetometers & Operator & Aeroplane \\
\hline FRAS-12 W & $\begin{array}{l}06 / 2011 \text { to } \\
10 / 2012\end{array}$ & $0.2 \times 2$ & 82584 & $60 \mathrm{~m}$ & $\begin{array}{c}\text { Geometrics } \\
\text { G-823A }\end{array}$ & Novatem Inc. & $\begin{array}{c}\text { Piper Navajo } \\
\text { PA31 }\end{array}$ \\
\hline FRAS-12 E & $\begin{array}{l}06 / 2011 \text { to } \\
10 / 2012\end{array}$ & $0.2 \times 2$ & 58800 & $60 \mathrm{~m}$ & $\begin{array}{c}\text { Geometrics } \\
\text { G-823A }\end{array}$ & Novatem Inc. & $\begin{array}{c}\text { Piper Navajo } \\
\text { PA31 }\end{array}$ \\
\hline TROFI-14 W & $\begin{array}{l}06 / 2014 \text { to } \\
11 / 2014\end{array}$ & $1 \times 10$ & 19052 & $200 \mathrm{~m}$ & $\begin{array}{c}\text { Geometrics } \\
\text { G-823A }\end{array}$ & $\begin{array}{l}\text { Eon Geoscience } \\
\text { Inc. }\end{array}$ & $\begin{array}{c}\text { Piper Navajo } \\
\text { PA31 }\end{array}$ \\
\hline TROFI-14 C & $\begin{array}{l}06 / 2014 \text { to } \\
11 / 2014\end{array}$ & $0.5 \times 5$ & 33500 & $200 \mathrm{~m}$ & $\begin{array}{c}\text { Geometrics } \\
\text { G-822A }\end{array}$ & $\begin{array}{l}\text { Eon Geoscience } \\
\text { Inc. }\end{array}$ & $\begin{array}{c}\text { Piper Navajo } \\
\text { PA31 }\end{array}$ \\
\hline TROFI-14 E & $\begin{array}{c}07 / 2014 \text { to } \\
09 / 2014\end{array}$ & $0.25 \times 2.5$ & 38658 & $60 \mathrm{~m}$ & $\begin{array}{c}\text { Geometrics } \\
\text { G-822A }\end{array}$ & Novatem Inc. & $\begin{array}{c}\text { Piper Navajo } \\
\text { PA31 }\end{array}$ \\
\hline
\end{tabular}

A number of filtering and image enhancements have been subsequently calculated from the magnetic total field to enhance specific magnetic trends and anomalies. Filtering and derivative calculations, especially the normalised tilt-derivative filtering (TDR) (Fig. 3; Miller \& Singh, 1994; Verduzco et al., 2004), helped to define different basement domains, subvertical geological boundaries, faults and dykes that are discussed in this paper. The TDR filter increased the amplitude of the magnetic total field anomalies and provided an effective alternative to the vertical derivative to map the continuity of the dykes that crop out only very locally in the terrain (Fig. 3A). Tilt angle responses vary between positive values over the source, zero over or near the edge, and negative values outside the body (Cooper \& Cowan, 2006). This sign variation is particularly useful when attempting to detect the relative contrast in magnetisation. In order to depict magnetic anomalies more clearly we have presented only the positive values of the TDR in a separate map (Figs. 3B \& 5).

\section{Mafic dykes}

For descriptive purposes, we find it expedient to subdivide the mafic dykes occurring in the Caledonides of Finnmark into three groups on the basis of their age. In each case, the ages have been determined by isotopic dating using a variety of methods, namely $\mathrm{K}-\mathrm{Ar}$ (both whole rock and clinopyroxene), ${ }^{40} \mathrm{Ar}-{ }^{39} \mathrm{Ar}$ (both whole rock and plagioclase), Sm-Nd and U-Pb (zircon). The three groups are: 1. Ediacaran metadolerites; 2. Late Devonian dolerites; 3 . Carboniferous dolerites.

\section{Ediacaran metadolerite dykes}

Mafic dykes of Late Neoproterozoic, Ediacaran age are known specifically from Varanger Peninsula where initial K-Ar dating in the northern part of the peninsula (Barents Sea Region - BSR) had yielded an approximate intrusion age of c. $650 \mathrm{Ma}$ (Beckinsale et al., 1975). Earlier, Roberts (1972) had referred to these dykes as metadolerites to distinguish them from the nonmetamorphosed dolerites which occur mainly in eastern areas of the peninsula and were subsequently $\mathrm{K}$ Ar-dated to c. $362 \mathrm{Ma}$ (Beckinsale et al., 1975).

The metadolerites are particularly common in two thrust sheets in the western and central parts of the BSR and in the overlying Tanahorn Nappe (Fig. 1), especially in the well exposed coastal areas where they occur as swarms, and were first recorded by Holtedahl (1918). The dykes trend between NE-SW and ENE-WSW and lie parallel or subparallel to the axial surfaces of the ubiquitous Caledonian folds in the area (Roberts, 1972; Rice \& Reiz, 1994). The subvertical dykes are generally 1 to $3 \mathrm{~m}$ in thickness, rarely up to $10 \mathrm{~m}$, and carry the same slaty cleavage or schistosity as the axial surfaces of the folds and country rocks. Most dykes are difficult to follow far inland, but a few of the thickest ones can be mapped discontinuously over several kilometres. Earlier, both Holtedahl (1918) and Roberts (1972) had surmised that the dykes were likely to have been intruded during the main folding episode, but the K-Ar dating study of Beckinsale et al. (1975) questioned this conclusion. Later detailed work by Rice \& Reiz (1994) and new K-Ar dating (Rice et al., 2004) showed that the dyke intrusion clearly predated the folding and metamorphism, a main tectonothermal event which is now considered to be of Early Ordovician age (Rice \& Frank, 2003). The metadolerite dykes have an age of approximately $577 \mathrm{Ma}$ (Rice et al., 2004).

The petrography of the metadolerites has been described in some detail by Roberts (1975) and mentioned in Rice et al. (2004). Despite the pervasive metamorphic alteration, most samples studied in thin-section show a relict ophitic to subophitic texture. Plagioclase and clinopyroxene are the dominant minerals, the latter quite extensively chloritised, with subordinate phases represented by ilmeno-magnetite, magnetite, pyrite, epidote, quartz, calcite and some titanite. A geochemical study of the metadolerite dykes showed them to be 


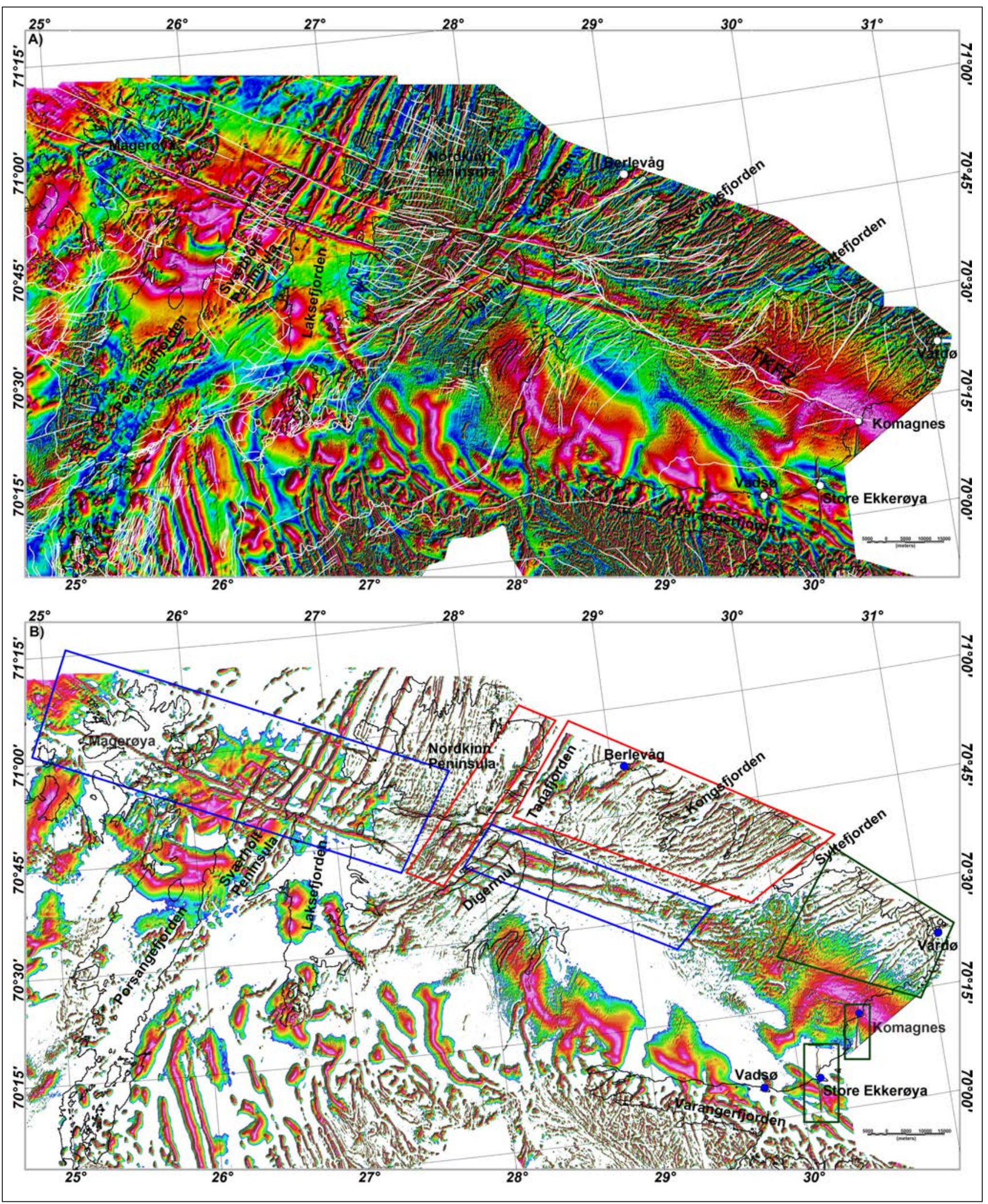

Figure 3. (A) Tilt-derivative map of aeromagnetic data of the northern Finnmark Caledonide region between Magerøya and eastern Varanger Peninsula. The mapped and interpreted faults are shown with solid white lines. (B) Map depicting the different mafic dyke groups. The three discussed dyke groups based on their ages are outlined by coloured boxes. NE-SW to NNE-SSW and ENE-WSW Ediacaran metadolerites (red boxes), NE-SW and also N-S Late Devonian dolerites (green boxes), and WNW-ESE Carboniferous dolerites (blue boxes). Abbreviation: TKFZ - Trollfjorden-Komagelva Fault Zone. 
comparable to abyssal tholeiites, though with transitional features reminiscent of continental margins (Roberts, 1975).

Metadolerite dykes are also fairly abundant locally within two of the main nappe complexes - the Laksefjord and Kalak nappe complexes - which together cover about $70 \%$ of the Caledonides in Finnmark. These particular metadolerites, in places richly garnetiferous in the higher thrust sheets in western Finnmark and commonly boudinaged, have not been dated isotopically, except in Troms county (c. 580 Ma; Zwaan \& van Roermund, 1990). The dykes are assumed to have intruded during the main phase of Ediacaran rifting along the Baltoscandian margin of Baltica, which led to the development of the Iapetus Ocean. The similarly aged dykes in the thrust sheets of the BSR are likely to have been generated in this same extensional regime, at more than $200 \mathrm{~km}$ to the northwest of where we find them today (Rice, 2014).

\section{Late Devonian dolerite dykes}

Unmetamorphosed dolerite dykes that have been dated to Late Devonian time occur mainly in the eastern part of Varanger Peninsula both north and south of the Trollfjorden-Komagelva Fault Zone (TKFZ) (Roberts, 1975; Rice et al., 2004; Herrevold et al., 2009). Only nine such dykes are actually exposed, six to the north and three to the south of the TKFZ. The near-vertical dykes vary greatly in thickness from tens of centimetres up to $16 \mathrm{~m}$ and mostly trend NE-SW north of the fault zone. To the south of the TKFZ the trends are generally $\mathrm{N}-\mathrm{S}$, and one such dyke (at Komagnes; Fig. 1) could be traced directly into the fault zone with the help of a handborne proton-magnetometer until its magnetic signature faded (Karpuz et al., 1993; Herrevold et al., 2009). The dolerite dykes cut the pervasive cleavage and related folds in the country rocks and commonly show pseudohexagonal to reticulate columnar jointing, as well as distinctive orange-brown weathering colours. In thin-section, the dolerites are dominated by plagioclase and clinopyroxene (mostly pigeonite) with only minor alteration features, and textures are ophitic to subophitic, rarely glomeroporphyritic (Roberts, 1975). The main opaque mineral phase is ilmeno-magnetite, and accessories include apatite, phlogopitic biotite and zircon. The geochemistry of these dykes is indicative of intrusion in a continental margin setting, and most likely during a rifting phase known from nearby areas on the Kola Peninsula in Russia (Guise \& Roberts, 2002). In this context, the dykes are likely to represent feeders to Late Devonian basaltic lavas also known from areas in Northwest Russia.

The Devonian age of the dolerite dykes on Varanger was first indicated by the $\mathrm{K}-\mathrm{Ar}$ whole-rock dating of Beckinsale et al. (1975), pointing to an approximate age of around $362 \mathrm{Ma}$. Subsequently, ${ }^{40} \mathrm{Ar}^{-39} \mathrm{Ar}$ dating of plagioclase from three of these dykes yielded age spectra of c. 369, 375 and $378 \mathrm{Ma}$, interpreted to represent their crystallisation ages and rounded off to circa $370 \mathrm{Ma}$ (Guise \& Roberts, 2002), i.e., Famennian, latest Devonian. Another comparable dolerite dyke from Hamningberg had earlier been dated by $\mathrm{U}-\mathrm{Pb}$ on zircon, giving an upper discordia intercept date of $567.1+30 /{ }_{-23} \mathrm{Ma}$ and a lower intercept of $392^{+25 /}$. $\mathrm{Ma}$ (Roberts \& Walker, 1997). The former date was then considered by these authors to represent the emplacement age, and the latter a Late Devonian thermal overprint. Rice et al. (2004) correctly rejected this explanation, favouring Late Devonian as the time of intrusion, and this re-interpretation was later accepted by Herrevold et al. (2009) and Roberts (2011).

\section{Carboniferous dolerite dykes}

Dolerite dykes of post-Caledonian, Carboniferous age have been described from central and southeastern Magerøya (Curry, 1975; Andersen, 1979; Roberts et al., 1991; Lippard \& Prestvik, 1995, 1997; Roberts et al., 2003) and also from the northwestern coast of the Digermul Peninsula (Beckinsale et al., 1975). On Magerøya, an $8 \mathrm{~m}$-thick, vertical dyke in the middle of the island follows a NW-SE-trending fault over a distance of 3.8 $\mathrm{km}$, and was the subject of a K-Ar and geochemical investigation (Roberts et al., 1991). Other dykes, up to 15 $m$ in thickness and also trending between NW-SE and WNW-ESE, occur farther to the southeast on Magerøya and one has been dated using the ${ }^{40} \mathrm{Ar} /{ }^{39} \mathrm{Ar}$ method (Lippard \& Prestvik, 1997). Both the dykes and the faults tend to form linear depressions in the landscape, and such NW-SE-trending faults are common on the island, some exposing breccias and gouges (Andersen, 1979).

Petrographically, the fresh unmetamorphosed dykes are similar with a primary mineralogy consisting of plagioclase, clinopyroxene, magnetite with lamellae of ilmenite, olivine (pseudomorphed) and leucoxene, with minor apatite, biotite and zircon. Textures are ophitic to subophitic. Geochemically, the dykes are akin to continental within-plate tholeiites (Roberts et al., 1991; Lippard \& Prestvik, 1997). Further geochemical data were reported by Rice et al. (2004) who also noted that the dolerite dyke on Digermul Peninsula is geochemically comparable to the dykes on Magerøya.

A first attempt at isotopic dating of the dolerite dykes on Magerøya produced $\mathrm{K}-\mathrm{Ar}$ ages on three pyroxene separates of c. 312, 302 and $266 \mathrm{Ma}$ (Roberts et al., 1991). Later, ${ }^{40} \mathrm{Ar} /{ }^{39} \mathrm{Ar}$ analyses on whole-rock and plagioclase samples yielded more precise ages of c. 340 and $337 \mathrm{Ma}$, respectively (Lippard \& Prestvik, 1997). A conventional $\mathrm{K}-\mathrm{Ar}$ analysis on the same whole-rock sample gave a date of c. $301 \mathrm{Ma}$. This suggested to Lippard \& Prestvik (1997) that the earlier reported, three K-Ar ages were too young, and that the true age of dyke emplacement is around $337 \mathrm{Ma}$, i.e., Visean. Full analytical details are given in the two, above-mentioned publications. 
The dyke on Digermul Peninsula had earlier been dated by the K-Ar whole-rock method to $332 \pm 10 \mathrm{Ma}$ (Beckinsale et al., 1975). Combined with the geochemical data of Rice et al., (2004) on this same dyke, this clearly suggests that this $c$. NW-SE-trending dyke is also of Early Carboniferous age. Two more dolerite dykes are exposed along the coast $c .8 \mathrm{~km}$ southwest of the $\mathrm{K}-$ Ar-dated dyke. As we shall see later, there are reasons for believing that these dykes are also of Carboniferous age.

\section{Fault systems in northern Finnmark}

Lineament investigations covering Finnmark and adjacent areas in Northwest Russia based on satellite imagery have shown that many such lineaments are major shear zones, fault zones or principal faults which have been studied in the field in considerable detail (Karpuz et al., 1993; Roberts et al., 1997; Gabrielsen et al., 2002; Herrevold et al., 2009). Some of these faults are shown on the TDR map of magnetic data (Fig. 3A). Many of the main faults, mostly vertical or steeply dipping, are shown in Fig. 1, but for the county as a whole the reader is referred to the compilations by Lippard \& Roberts (1987) and Roberts \& Lippard (2005). In summary, the principal fault sets trend NW-SE to WNW-ESE, NE-SW and E-W. Dip-slip normal displacements generally prevail, with down-steps towards the coastline, i.e., to the northeast along most NW-SE faults and to the northwest along NE-SW faults, in extensional regimes associated with the formation of Late Palaeozoic and Mid Mesozoic, offshore sedimentary basins (Faleide et al., 1984; Gabrielsen et al., 1990; Bugge et al., 1995). On Varanger Peninsula, studies along several WNW-ESE faults have revealed the presence of incohesive breccias and gouge with consistent northward downthrows of the hangingwall blocks (Karpuz et al., 1993; Herrevold et al., 2009).

The most prominent lineament in northern Finnmark, the multiply reactivated Trollfjorden-Komagelva Fault Zone (Fig. 1), extends southeastwards into the Timans of Northwest Russia (Roberts \& Olovyanishnikov, 2004). To the northwest it can be followed far out on the continental shelf (Gabrielsen et al., 1990), but its trasé is masked just northeast of Magerøya by a $25 \mathrm{~km}$-long prong of inferred Magerøy Nappe rocks on the seabed, revealed by high-resolution bathymetric data (Fig. 4). Major dextral translation along the TKFZ occurred in Early Ordovician time (Rice \& Frank, 2003), with little if any strike-slip movement recorded during the later parts of the Caledonian cycle. Thus, the Silurian-emplaced Magerøy Nappe has effectively blanketed the TKFZ trasé, with only minor E-W fractures (possible Carboniferous faults) noticeable on the seabed (Fig. 4).

The dyke-related, NW-SE-trending faults in the Magerøy Nappe on Magerøya are also very conspicuous on the Sværholt Peninsula to the southeast, as well as farther east on the Nordkinn Peninsula and the mainland directly to the south, all areas which form part of the Kalak Nappe Complex. As we shall see later, this particular and extensive fault set is highlighted in the new high-resolution aeromagnetic data (Fig. 3A).

\section{Discussion}

Potential field studies and particularly high-resolution aeromagnetic data have long been known and employed to complement field investigations and mapping, notably in poorly exposed regions and also on continental shelves in different parts of the world (e.g., Åm, 1973; Mettone et al., 1987; Nielsen, 1987; Vasilieva \& FrankKamenetsky, 2003; Olesen et al., 2004; Genske et al., 2012). Where not exposed on the present-day surface, plutons, dyke swarms and even ore deposits identified by geophysical methods are commonly referred to as 'blind' features (e.g., Genske et al., 2012), in much the same sense as structural geologists refer to blind thrusts, meaning that these particular faults remain concealed, at varying depths, having not managed to propagate to the terrain surface. Prominent and large, positive magnetic anomalies are clearly visible in the aeromagnetic maps, many of which extend northwestwards beneath the thin Caledonian nappes from the Neoarchaean and Palaeoproterozoic terranes of the Fennoscandian Shield (cf., Åm, 1975). These will be the subject of a future contribution, now in preparation, and are therefore not discussed in the present paper.

In order to better understand the causes of magnetic anomalies, especially in the near surface, we need to know the magnetic properties of the rocks (e.g., susceptibility and magnetic remanence). For the study area, there is only an inadequate petrophysical database available, from NGU, and mainly for the diverse metasedimentary lithologies of the region. Two maps, density and susceptibility, have been compiled based on these data for the whole of Norway (Olesen et al., 2010). Unfortunately, these data are not dense enough to include the properties of the dykes and the only measurements that we could find for the dykes are limited to the measurements reported for two mafic dykes on Magerøya (Roberts et al., 2003). The average susceptibility for the bedrock on the island of Magerøya based on the NGU petrophysical database is about 1.6 (10-3 SI), whereas the measurements for the two mafic dykes are 51 and 62 (10-3 SI). Such a sharp contrast in susceptibility values between dykes and country rock, if valid for other parts of Caledonide Finnmark, will explain the clear appearance of mafic dykes as linear anomalies in the magnetic maps.

In this contribution, many of the linear, NW-SE- to WNW-ESE-trending, positive magnetic anomalies 


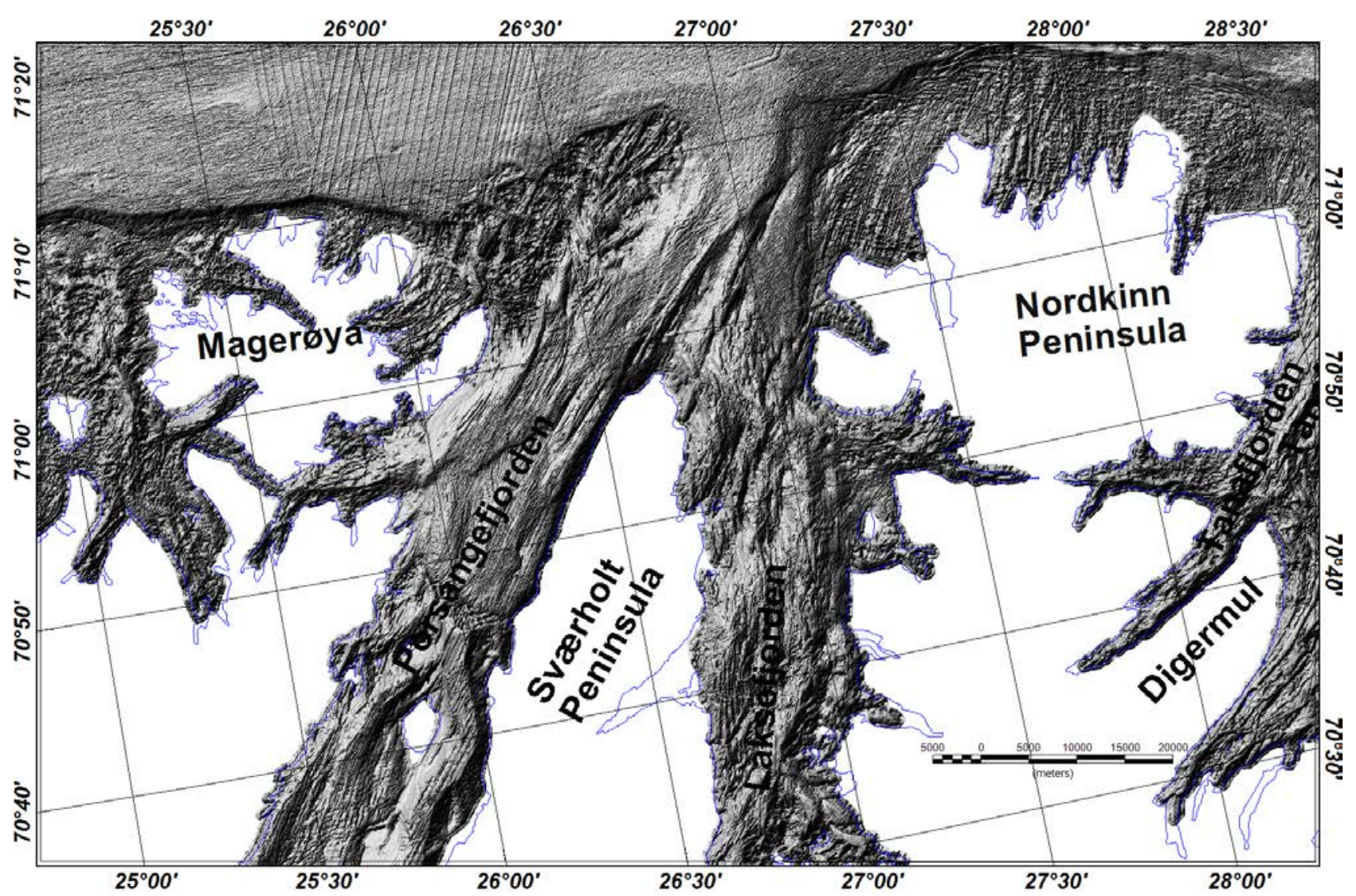

Figure 4. Multibeam bathymetric image showing the extension of what we assume to be the Magerøy Nappe along strike on the seabed directly northeast of Magerøya (see Fig. 1 for location). The Magerøy Nappe was thrust-emplaced to its present position in Mid Silurian time and appears to effectively conceal the offshore prolongation of the TKFZ in this particular part of its trase. The bathymetry data are by courtesy of the MAREANO programme (http://mareano.no/).

extending from Magerøya across the Porsangerfjord and Sværholt Peninsula (Fig. 3A, B) are, in our view, indicative of the presence of blind mafic dykes along at least large parts of their trasés. These particular dykes are almost certainly dolerites and of Early Carboniferous age, as are the ones exposed on Magerøya. There, the dykes are not continuously exposed in the terrain, tending to thin and wedge out along strike. Where they disappear, the propagating tips of the dykes are likely to be present in the subsurface at shallow depths, as indicated by the continuity of the aeromagnetic anomaly (Fig. 3A, B). The main dyke in central Magerøya is also fault-related (Roberts et al., 1991), which led to the interpretation that the NW-SE-trending faults are basically dip-slip normal structures coinciding with a major phase of Carboniferous rifting and extension that is known to have occurred during this period in the adjacent southwestern Barents Sea (Gabrielsen, 1984; Berglund et al., 1986; Gabrielsen \& Færseth, 1989; Samuelsberg et al., 2003).

Such NW-SE to WNW-ESE faults are also common on the Sværholt and Nordkinn peninsulas, and mainland south of Nordkinn (Fig. 1), and accordingly it is not surprising that the linear, positive, magnetic anomalies also follow many of these structures (Fig. 3A). On
Sværholt Peninsula, exposed dolerite dykes of this trend have not been reported, but they are inferred by us to be present in the subsurface along many of these faults, judging by the colinearity of the prominent magnetic anomalies with the NW-SE faults (Fig. 3B). A few metadolerite dykes do occur on this peninsula, but they are generally parallel or subparallel to the strike of the metasedimentary rocks, $c$. NE-SW; they are clearly older than the Carboniferous dykes, and most likely Ediacaran in age. Two small fragments of schistose metadolerite (but no dolerite) have been recorded in a fault breccia on Sværholt Peninsula.

Farther to the east, on Digermul Peninsula, the one WNW-ESE-trending dolerite dyke that has been isotopically dated as probably Visean also coincides with a linear magnetic anomaly, as do the two dykes along the coast farther to the southwest (Fig. 3B). Although this is the easternmost exposed Carboniferous dyke yet encountered in northern Finnmark, its associated linear magnetic anomaly can be followed quite clearly across Tanafjorden onto Varanger Peninsula for a further 50 $\mathrm{km}$ where the anomaly branches and appears to become disjointed and terminate in the vicinity of the TKFZ (Fig. 3A, B). Thus, we feel confident in suggesting that 
the mafic dyke is present in the subsurface beneath the anomaly. Subparallel linear magnetic anomalies also occur at the northernmost tip of Digermul Peninsula and along the trasé of the TKFZ in Tanafjorden, and are likely to denote the presence of blind dolerite dykes of Carboniferous age. Faults of this trend, or a subparallel trend, are well known from Varanger Peninsula. The multiply reactivated TKFZ, for example, is known to carry a concealed half-graben in its hangingwall in its extension across outer Varangerfjorden (Roberts et al., 2011), and this component of faulting and sedimentary infill was interpreted by these authors to relate to Carboniferous extension. A similar half-graben basin of Carboniferous age is known from the offshore prolongation of the TKFZ on the continental shelf northwest of Magerøya (Gabrielsen et al., 1990).

The Late Devonian dolerite dykes, as mentioned earlier, occur principally in eastern Varanger Peninsula, although one that has been $\mathrm{K}-\mathrm{Ar}$-dated to $c .362 \mathrm{Ma}$ (Beckinsale et al., 1975) crops out in the northwest just beneath the Tanahorn Nappe, $5 \mathrm{~km}$ east of Berlevåg (Fig. $3 \mathrm{~B})$. Other dykes of this age may well be present across the peninsula, awaiting future isotopic dating. Looking at the northeastern region, however, where six exposed Devonian dykes have been recorded, and examining the new aeromagnetic map, we feel safe in declaring that the NE-SW to NNE-SSW, linear, positive magnetic anomalies are indicating that perhaps up to 20 , mostly blind, Late Devonian dykes can be detected in the area between Vard $\varnothing$ and Syltefjorden (Figs. 3B \& 5). Some appear to exceed $20 \mathrm{~km}$ in length on land, cutting across lithological boundaries and folds, but their northeastern prolongations offshore are uncertain. However, there are indications from a tilt-derivative filter map of the magnetic total field (Gernigon et al., 2014, fig. 4) that some of these thicker dolerite dykes may be followed for up to $30 \mathrm{~km}$ onto the Finnmark Platform.

South of the TKFZ, there are two prominent, isotopically dated, Late Devonian dykes exposed at Komagnes and Store Ekkerøya (Fig. 1). The 2.5 m-thick, N-S, Komagnes dyke had earlier been traced northwards into the fault zone with a hand-held magnetometer (Karpuz et al., 1993), but with the aid of the new aeromagnetic map we see that the dyke swings into a NNE-SSW trend north of the fault (Fig. 5), suggesting that there was little if any strike-slip movement along the TKFZ after Late Devonian time. Another revelation is that the dyke can be followed offshore to the south over a distance of at least $8 \mathrm{~km}$ (Fig. 5). The Store Ekkerøya dolerite dyke is thicker, $c .16 \mathrm{~m}$, and can clearly be traced up to $10 \mathrm{~km}$ to the north with two small forked branches near the coast. Moreover, the prominent linear anomaly extends for a further c. $10 \mathrm{~km}$ offshore to the south (Fig. 5).

The older, Ediacaran metadolerite dykes are particularly well represented on the new aeromagnetic map in the Barents Sea Region of Varanger Peninsula between western Kongsfjorden and Syltefjorden (Fig. 3) where they occur as swarms in two thrust sheets below the Tanahorn Nappe. Many of these mafic dykes are actually included on three 1:50,000 bedrock map sheets from the area (Siedlecka, 1984, 1987, 1989), which prompted Brönner et al. (2009) and Gernigon et al. (2014) to suggest that the dykes probably contributed to the higher magnetic response in this area based on information gained from the earlier, high-sensitivity, aeromagnetic surveys BAS-06 and BASAR-08. Now we know that this really is the case, with many of the thickest dykes or sets of dykes represented by linear positive magnetic anomalies traceable up to $25 \mathrm{~km}$ or more inland, and also extending offshore over indeterminate distances. The Tanahorn Nappe also includes a swarm of metadolerite dykes, best seen in the intertidal zone along the coast near Berlevåg, and the basal part of this nappe is also marked by a prominent positive magnetic anomaly extending into nearby Tanafjorden. A similar anomaly is seen in easternmost Nordkinn Peninsula, reflecting partly exposed metadolerite dykes but also magnetiterich sandstones, and can be followed southwards close to the mylonitic base of the Kalak Nappe Complex. It is noteworthy that these sandstones show similar magnetic lineaments and are broadly parallel to the dykes but with less continuity. In order to distinguish dykes from these magnetite-rich sandstones we have depicted only those regions where dykes have been observed partly on the ground in Fig. 3B. However, there still may be lineaments ascribed to the sandstones in these particular regions. Also, the resolution of the discussed aeromagnetic data has to be taken into account for resolving the presence of dykes in the region. For example, many of the mafic dykes of only 2-10 m thickness will not be resolved individually but will be included in some of the broader linear magnetic anomalies. Therefore, these particular anomalies are the result of a combination of magnetic responses from both dykes and sandstones.

\section{Conclusions}

Results from the new high-resolution aeromagnetic data reported here provide confirmatory evidence for the existence of both metadolerite and unmetamorphosed dolerite dykes transecting the Caledonian nappes and subjacent (par)autochthonous lithostratigraphical successions in this part of Finnmark. Three ages of mafic dykes are known from isotopic dating studies - Ediacaran, Late Devonian and Early Carboniferous - but actual dyke outcrop in the case of the two younger dyke sets is very limited.

High-amplitude magnetic responses in two thrust sheets in northwestern Varanger Peninsula, north of the TKFZ and beneath the Tanahorn Nappe, are clearly shown to relate to swarms of Ediacaran metadolerite dykes. Moreover, the trasés of individual dykes discontinuously exposed on the surface can be followed as linear positive 


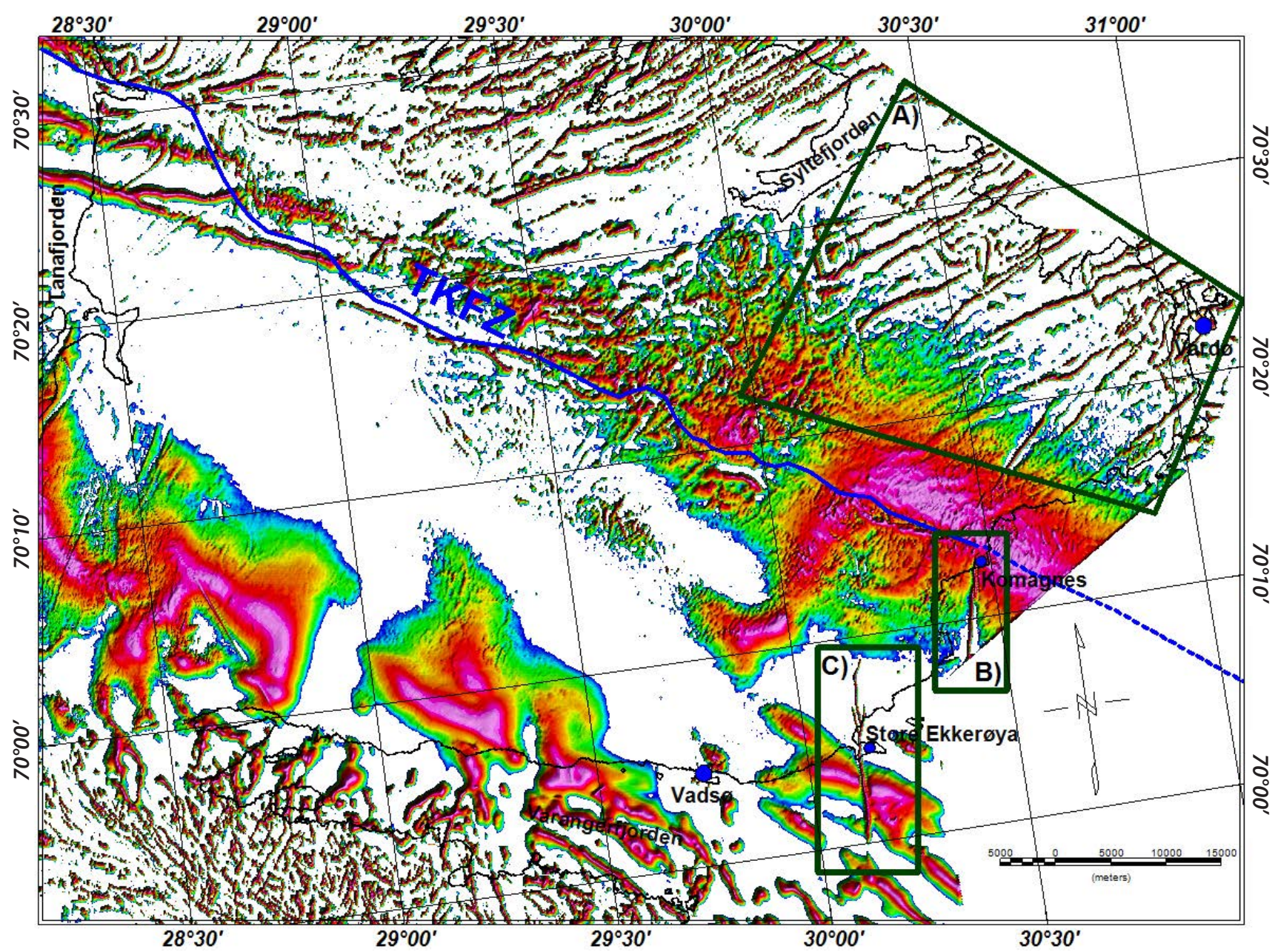

Figure 5. Eastern Varanger Peninsula; an enlarged version of part of Fig. $3 B$ to emphasise the Devonian dykes (the location is also marked in Fig. 1). (A) Six such dykes are exposed along the coast between Vardø and Syltefjorden (cf., Fig. 3) but several more are highlighted by the linear positive magnetic anomalies. (B) and (C) South of the TKFZ, the two dykes with limited outcrop occur at Komagnes and Store Ekkerøya and are clearly recognised by the linear anomalies, also offshore. Just to the north of Store Ekkerøya the main dyke shows two small branches on either side of the main dyke. Abbreviation: TKFZ - Trollfjorden-Komagelva Fault Zone.

magnetic anomalies over distances of $25 \mathrm{~km}$ inland. Their extent offshore is as yet unknown.

In eastern Varanger Peninsula, 8-9 dolerite dykes of Late Devonian age occur in discontinuous or limited outcrop. The new aeromagnetic data show, however, that up to 20 such dykes can be identified in the subsurface in the region between Vardø and Syltefjorden, north of the TKFZ, based on their linear positive magnetic anomaly signatures. South of the TKFZ, two Late Devonian dolerite dykes, well known from small coastal outcrops, are clearly visible as linear positive magnetic anomalies both on land and offshore beneath the sea-floor of Varangerfjorden.

The most spectacular manifestations of what we consider to represent blind dolerite dykes are seen in connection with linear positive magnetic anomalies relating to Early Carboniferous dolerite dykes exposed on Magerøya and western Digermul Peninsula. These prominent linear anomalies follow many of the mapped NW-SE- to WNW-ESE-trending faults that have disrupted the Caledonian nappes in this part of Finnmark, and some are continuous over distances of more than $100 \mathrm{~km}$ from Magerøya to western Varanger Peninsula. These particular dykes and faults have been interpreted as relating to a major period of extension and rifting that occurred in the SW Barents Sea and adjacent onshore areas of Norway in Carboniferous time.

Acknowledgements. This study is funded by the Mineral Resources In North Norway (MINN) programme which is part of a recently initiated Norwegian governmental strategy to develop the mineral industry in Norway. We would like to thank Odleiv Olesen as the project leader of the magnetic fixed-wing surveys at NGU and Marie-Andrée Dumais for carrying out a quality control of aeromagnetic data during the data acquisition. We also thank the two Canadian geophysical companies Noatem Airborne geophysics and EON Geosciences Inc. for the data acquisition. We are grateful to the reviewers, Christine Fichler and Stephen Lippard, for their insightful comments on the submitted manuscript. In particular, suggestions by Dr. Fichler led to several additions and improvements in the final text. 


\section{References}

Andersen, T.B. 1979: The geology of SW Magerøy, with special emphasis on the tectono-metamorphic development. Cand. real. thesis, University of Bergen, $338 \mathrm{pp}$.

Andersen, T.B. 1981: The structure of the Magerøy Nappe, Finnmark, North Norway. Norges geologiske undersøkelse 363, 1-23.

Andersen, T.B. 1984: The stratigraphy of the Magerøy Supergroup, North Norway. Norges geologiske undersøkelse Bulletin 395, 25-37.

Banks, N.L., Edwards, M.B., Geddes, W.P., Hobday, D.K. \& Reading, H.G. 1971: Late Precambrian and Cambro-Ordovician sedimentation in East Finnmark. Norges geologiske undersøkelse 296, 197-236.

Barrère, C., Ebbing, J. \& Gernigon, L. 2009: Offshore prolongation of Caledonian structures and basement characterisation in the western Barents Sea from geophysical modelling, Tectonophysics 470,71-88.

Beckinsale, R. D., Reading, H. G. \& Rex, D. C. 1975: Potassium-argon ages for basic dykes from east Finnmark: Stratigraphical and structural implications. Sconish Journal of Geology 12, 51-65.

Berglund, T.L., Augustson, J.H., Færseth, R.B. \& Ramberg-Moe, H. 1986: The evolution of the Hammerfest basin. In Spencer, A.M. (ed.): Habitat of hydrocarbons on the Norwegian continental margin, Graham \& Trotman, London, pp. 319-338.

Brönner, M., Gernigon, L., Ebbing, J., Olsesen, O., Roberts, D., Barrére, C. \& Koziel, J. 2009: Barents Sea Aeromagnetic Remapping BASAR08 - acquisition, processing and interpretation. Norges geologiske undersøkelse Report 2009.020, 150 pp.

Bugge, T., Mangerud, G., Elvebakk, G., Mørk, A., Nilsson, I., Fanavoll, S. \& Vigran, J.O. 1995: The Upper Palaeozoic succession on the Finnmark Platform, Barents Sea. Norsk Geologisk Tidsskrift 75, 3-30.

Cooper, G.R.J. \& Cowan, D.R. 2006: Enhancing potential field data using filters based on the local phase. Computers and geosciences 32, $1585-1591$

Corfu, F., Torsvik, T.H., Andersen, T.B., Ashwal, L.D., Ramsay, D.M \& Roberts, R.J. 2006: Early Silurian mafic-ultramafic and granitic plutonism in contemporaneous flysch, Magerøy, northern Norway: $\mathrm{U}-\mathrm{Pb}$ ages and regional significance. Journal of the Geological Society of London 162, 291-301.

Corfu, F., Gerber, M., Andersen, T.B., Torsvik, T.H. \& Ashwal, L.D. 2011 Age and significance of Grenvillian and Silurian orogenic events in the Finnmarkian Caledonides, northern Norway. Canadian Journal of Earth Sciences 48, 419-440.

Curry, C.J. 1975: A regional study of the geology of the Magerøy basic igneous complex and its envelope. Ph.D. thesis, University of Dundee, Scotland, $244 \mathrm{pp}$.

EON Geosciences Inc. 2015: Troms-Finnmark fixed wing aeromagnetic survey 2014 (TROFI-14). Report EON Geosciences Inc., Montréal, Quebec, Canada, 34 pp.

Faleide, J.I., Gudlaugsson, S.T. \& Jacquart, G. 1984: Evolution of the western Barents Sea. Marine Petrology and Geology 1, 123-150.

Føyn, S. 1967: Dividal-gruppen ("Hyolithis-sonen") i Finnmark og dens forhold til de eokambrisk-kambriske formasjoner. Norges geologiske undersøkelse 249, 1-84.

Gabrielsen, R.H. 1984: Long-lived fault zones and their influence on the tectonic development of the southwestern Barents Sea. Journal of the Geological Society of London 141, 651-662.

Gabrielsen, R.H. \& Færseth, R.B. 1989: The inner shelf of North Cape, Norway, and its implications for the Barents Shelf - Finnmark Caledonide boundary. A comment. Norsk Geologisk Tidsskrift 69, 57-62.

Gabrielsen, R.H., Færseth, R.B., Jensen, N.L., Kalheim, J.E. \& Riis, F 1990: Structural elements of the Norwegian continental shelf Part 1: The Barents Sea Region. Norwegian Petroleum Directorate Bulletin $6,33 \mathrm{pp}$.

Gabrielsen, R.H., Braathen, A., Dehls, J. \& Roberts, D. 2002: Tectonic lineaments of Norway. Norsk Geologisk Tidsskrift 82, 153-174.
Gayer, R.A., Rice, A.H.N., Roberts, D., Townsend, C. \& Welbon, A. 1987: Restoration of the Caledonian Baltoscandian margin from balanced cross-sections: the problem of excess continental crust. Transactions of the Royal Society of Edinburgh: Earth Sciences 78, 197-217.

Genske, F.S., Flood, R.H. \& Lackie, M.A. 2012: Geophysical characterisation of a blind I-type pluton emplaced within the Bundarra Suite S-type granites of the New England Batholith. Australian Journal of Earth Sciences 59, 435-446.

Gernigon, L., Marello, L., Mogaard, J.O., Werner, S.C. \& Skilbrei, J.R. 2007: Barents Sea Aeromagnetic Survey BAS-06: Acquisitionprocessing report and preliminary interpretation. Norges geologiske undersøkelse Report 2007.035, 142 pp.

Gernigon, L., Brönner, M., Roberts, D., Olesen, O., Nasuti, A. \& Yamasaki, T. 2014: Crustal and basin evolution of the southwestern Barents Sea: from Caledonian orogeny to continental breakup. Tectonics 33. doi:10.1002/2013TC003439

Guise, P.G. \& Roberts, D. 2002: Devonian ages from 40Ar/39Ar dating of plagioclase in dolerite dykes, eastern Varanger Peninsula, North Norway. Norges geologiske undersøkelse Bulletin 440, 27-37.

Herrevold, T., Gabrielsen, R.H. \& Roberts, D. 2009: Structural geology of the southeastern part of the Trollfjorden-Komagelva Fault Zone, Varanger Peninsula, Finnmark, North Norway. Norwegian Journal of Geology 89, 305-325.

Hinze, W.J., Von Frese, R.B. \& Saad, A.H. 2013: Gravity and Magnetic Exploration: Principles, Practices and Applications. Cambridge University Press, New York, $512 \mathrm{pp}$.

Holtedahl, O. 1918: Bidrag til Finnmarkens geologi. Norges geologiske undersøkelse 84, 1-314.

Karpuz, M.R., Roberts, D., Olesen, O., Gabrielsen, R.H. \& Herrevold, T. 1993: Application of multiple data sets to structural studies on Varanger Peninsula, northern Norway. International Journal of Remote Sensing 14, 979-1003.

Kirkland, C.L., Daly, J.S. \& Whitehouse, M.J. 2006: Granitic magmatism of Grenvillian and Late Neoproterozoic age in Finnmark, Arctic Norway - constraining pre-Scandian deformation in the Kalak Nappe Complex. Precambrian Research 145, 24-52.

Kirkland, C.L., Daly, J.S., Chew, D.M. \& Page, L.M. 2008: The Finnmarkian Orogeny revisited: an isotopic investigation in eastern Finnmark, Arctic Norway. Tectonophysics 460, 158-177.

Lippard, S.J. \& Prestvik, T. 1995: Permo-Karbonske basaltganger på Magerøya - noen nye feltobservasjoner og foreløpige petrografiske og geokjemiske data. (Abstract). Geonytt 1, 45-46.

Lippard, S.J. \& Prestvik, T. 1997: Carboniferous dolerite dykes on Magerøy: new age determination and tectonic significance. Norsk Geologisk Tidsskrift 77, 159-163.

Lippard, S.J. \& Roberts, D. 1987: Fault systems in Caledonian Finnmark and the southern Barents Sea. Norges geologiske undersøkelse Bulletin 410, 55-64.

Marello, L., Ebbing, J. \& Gernigon, L. 2013: Basement inhomogeneities and crustal setting in the Barents Sea from a combined 3D gravity and magnetic model. Geophysical Journal International 132, 557584

Mettone, J.G., Ross, M.E. \& Greenough, J.D. 1987: Mesozoic dyke swarms of eastern North America. Geological Association of Canada, Special Paper 34, 279-288.

Miller, H.G. \& Singh, V. 1994: Potential-field tilt - a new concept for location of potential-field sources. Journal of Applied Geophysics 32, 213-217.

Nasuti, A., Roberts, D., Dumais, M.-A., Ofstad, F., Hyvönen, E., Stampolidis, A. \& Rodionov, A. 2015a: New high-resolution aeromagnetic and radiometric surveys in Finnmark and North Troms: linking anomaly patterns to bedrock geology and structure. Norwegian Journal of Geology 95, 217-243. http://dx.doi. org/10.17850/njg95-3-10.

Nielsen, T.F.D. 1987: Mafic dyke swarms in Greenland. Geological Association of Canada, Special Paper 34, 349-360.

Novatem 2012: Fixed wing magnetic and radiometric survey of the 
coastal area of Northwestern Norway (FRAS-E). Report, Novatem Airborne Geophysics, Mont-Saint Hilaire, Quebec, Canada, 36 pp.

Novatem 2014: Fixed wing magnetic and radiometric survey over the Troms-Finnmark region in Northern Norway (TROFI-14 E). Report, Novatem Airborne Geophysics, Mont-Saint Hilaire, Quebec, Canada, 29 pp.

Olesen, O., Roberts, D., Henkel, H., Lile, O.B. \& Torsvik, T.H. 1990: Aeromagnetic and gravimetric interpretation of regional structural features in the Caledonides of West Finnmark and North Troms, northern Norway. Norges geologiske undersøkelse Bulletin 419, 1-24.

Olesen, O., Henkel, H., Lile, O.B., Mauring, E. \& Rønning, J.S. 1992: Geophysical investigations of the Stuoragurra postglacial Fault, Finnmark, northern Norway. Journal of Pure of Applied Geophysics 29, 95-118.

Olesen, O., Smethust, M.A., Torsvik, T.H. \& Birdstrup, T. 2004: Sveconorwegian igneous complexes beneath the NorwegianDanish Basin. Tectonophysics 387, 105-130.

Olesen, O., Ebbing, J., Gellein, J., Gernigon, L., Koziel, J., Lauritsen, T., Mykelbust, R., Pascal, C., Sand, M., Solheim, A. \& Usov, S. 2010: New aeromagnetic and gravity compilations from Norway and adjacent areas - methods and applications. In Vining, B.A. \& Pickering, S.C. (eds.): Petroleum geology: from mature basins to new frontiers, Geological Society of London, pp. 559-586.

Rice, A.H.N. 2014: Restoration of the external Caledonides, Finnmark, North Norway. In Corfu, F., Gasser, D. \& Chew, D.M. (eds.): New perspectives on the Caledonides of Scandinavia and related areas, Geological Society of London, Special Publications 390, pp. 271299.

Rice, A.H.N. \& Reiz, W. 1994: The structural relations and regional tectonic implications of metadolerite dykes in the Kongsfjord Formation, North Varanger Region, Finnmark, N. Norway. Norsk Geologisk Tidsskrift 74, 152-165.

Rice, A.H.N. \& Frank, W. 2003: The early Caledonian (Finnmarkian) event reassessed in Finnmark: ${ }^{40} \mathrm{Ar} /{ }^{39} \mathrm{Ar}$ cleavage age data from NW Varangerhalvøya, N. Norway. Tectonophysics 374, 219-236.

Rice, A.H.N., Gayer, R.A., Robinson, D. \& Bevins, R.E. 1989: Strikeslip restoration of the Barents Sea Caledonides terrane, Finnmark, North Norway. Tectonics 8, 247-264.

Rice, A.H.N., Ntaflos, T., Gayer, R.A. \& Beckinsale, R.D. 2004. Metadolerite geochronology and dolerite geochemistry from East Finnmark, northern Scandinavian Caledonides. Geological Magazine 141, 301-318.

Roberts, D. 1972: Tectonic deformation in the Barents Sea Region of Varanger Peninsula, Finnmark. Norges geologiske undersøkelse 282, $1-39$.

Roberts, D. 1975: Geochemistry of dolerite and metadolerite dykes from Varanger peninsula, Finnmark, North Norway. Norges geologiske undersøkelse 322, 55-72.

Roberts, D. 1985: The Caledonian fold belt in Finnmark: a synopsis. Norges geologiske undersøkelse Bulletin 403, 161-178.

Roberts, D. 1995: Principal features of the structural geology of Rybachi and Sredni Peninsulas, and some comparisons with Varanger Peninsula. Norges geologiske undersøkelse Special Publication 7, 247-258.

Roberts, D. 2011: Age of the Hamningberg dolerite dyke, Varanger Peninsula, Finnmark: Devonian rather than Vendian - a revised interpretation. Norges geologiske undersøkelse Bulletin 451, 32-36.

Roberts, D. \& Walker, N. 1997: U-Pb zircon age of a dolerite dyke from near Hamningberg, Varanger Peninsula, North Norway, and its regional significance. Norges geologiske undersøkelse Bulletin 432, 95-102.

Roberts, D. \& Olovyanishnikov, V. 2004: Structural and tectonic development of the Timanide orogen. In Gee, D.G. \& Pease, V. (eds.): The Neoproterozoic Timanide Orogen of Eastern Baltica, Geological Society of London, Memoirs 30, pp. 47-57.

Roberts, D. \& Lippard, S.J. 2005: Inferred Mesozoic faulting in Finnmark: current status and offshore links. Norges geologiske undersøkelse Bulletin 443, 55-60.

Roberts, D. \& Siedlecka, A. 2012: Provenance and sediment routing of Neoproterozoic formations on the Varanger, Nordkinn, Rybachi and Sredni peninsulas, North Norway and Northwest Russia: a review. Norges geologiske undersøkelse Bulletin 452, 1-19.

Roberts, D., Mitchell, J.G. \& Andersen, T.B. 1991: A post-Caledonian dolerite dyke from Magerøy, North Norway: age and geochemistry. Norsk Geologisk Tidsskrift 71, 289-294.

Roberts, D., Olesen, O. \& Karpuz, M.R. 1997: Seismo- and neotectonics in Finnmark, Kola Peninsula and the southern Barents Sea. Part 1. Geological and neotectonic framework. Tectonophysics 270, 1-13.

Roberts, R.J., Torsvik, T.H., Andersen, T.B. \& Rehnström, E.F. 2003: The Early Carboniferous Magerøy dykes, northern Norway: palaeomagnetism and palaeogeography. Geological Magazine 140, 443-451.

Roberts, D., Chand, S. \& Rise, L. 2011: A half-graben of inferred Late Palaeozoic age in outer Varangerfjorden, Finnmark: evidence from seismic reflection profiles and multibeam bathymetry. Norwegian Journal of Geology 91, 191-200.

Samuelsberg, T.J., Elvebakk, G. \& Stemmerik, L. 2003: Late Palaeozoic evolution of the Fimmark Platform, southern Norwegian Barents Sea. Norwegian Journal of Geology 83, 351-362.

Robins, B. 1998: The mode of emplacement of the Honningsva ${ }^{\circ} \mathrm{g}$ Intrusive Suite, Magerøya, northern Norway. Geological Magazine 135, 231-244.

Siedlecka, A. 1984: Syltefjord, foreløpig berggrunnsgeologisk kart 2436-2, scale 1:50,000. Norges geologiske undersøkelse.

Siedlecka, A. 1985: Development of the Upper Proterozoic sedimentary basins of the Varanger Peninsula, East Finnmark, North Norway. Geological Survey of Finland Bulletin 331, 175-185.

Siedlecka, A. 1987: Båtsfjord 2435-3, berggrunnskart, M, scale 1:50,000. Norges geologiske undersøkelse.

Siedlecka, A. 1989: Kongsfjord - 2336-2, berggrunnskart M, scale 1:50,000. Norges geologiske undersøkelse.

Skilbrei, J.R. 1995: Aspects of the geology of the south-western Barents Sea from aeromagnetic data. (Extended abstract). Norges geologiske undersøkelse Bulletin 427, 64-67.

Skilbrei, J.R., Håbrekke, H., Olesen, O. \& Kihle, O. \& Macnab, R. 1991: Shaded relief aeromagnetic colour map of Norway and the Norwegian-Greenland and Barents Seas: Data compilation and examples of interpretation. NGU-Report 91, 269, pp.15.

Vasilieva, T. \& Frank-Kamenetsky, D. 2003: The application of aeromagnetic data for dyke swarm mapping (an example from the Ladoga region, Russia). Abstract, EGS - AGU - EUG Joint Assembly, European Union of Geosciences, General Assembly, 6 - 11 April 2003, Nice, France.

Verduzco, B., Fairhead, J.D. \& MacKenzie, C. 2004: New insights into magnetic derivatives from structural mapping. The Leading Edge 23, 116-119.

Vidal, G. 1981: Micropalaeontology and biostratigraphy of the Upper Proterozoic and Lower Cambrian sequence in East Finnmark, northern Norway. Norges geologiske undersøkelse Bulletin 362, 53 pp.

Zwaan, K.B. \& van Roermund, H.L.M. 1990: A rift-related mafic dyke swarm in the Corrovarre Nappe of the Middle Allochthon, Troms, North Norway, and its tectonometamorphic evolution. Norges geologiske undersøkelse Bulletin, 419, 25-44.

Åm. K. 1973: Geophysical indications of Permian and Tertiary igneous activity in the Skagerrak. Norges geologiske undersøkelse 287, 1-25.

Åm, K. 1975: Aeromagnetic basement complex mapping north of latitude $62^{\circ} \mathrm{N}$, Norway. Norges geologiske undersøkelse 316, 351-374. 
